\title{
Bone histomorphometry of broilers submitted to different phosphorus sources in growing and finisher rations
}

\author{
Rafael Carvalho de Oliveira(1), Luciano da Fontoura Costa(2), Evandro Abreu Fernandes(3), \\ Bauer Oliveira e Alvarenga ${ }^{(3)}$, Sérgio Russo Matioli ${ }^{(4)}$ and Marcelo Emílio Beletti $i^{(1)}$
}

\begin{abstract}
(1)Universidade Federal de Uberlândia (UFU), Instituto de Ciências Biomédicas, Dep. de Morfologia, Laboratório de Histologia, Rua Pará, no 1720, Umuarama, CEP 38400-902 Uberlândia, MG, Brazil. E-mail: rcobioin@ime.usp.br, mebeletti@ufu.br (2)Universidade de São Paulo (USP), Instituto de Física de São Carlos, Av. Trabalhador São Carlense, no 400, Caixa Postal 369, CEP 13560-970 São Carlos, SP, Brazil. E-mail: luciano@if.sc.usp.br (3)UFU, Fac.de Medicina Veterinária, Núcleo de Nutrição Animal, Rua Ceará, Bloco 2T, Umuarama CEP $38400-902$ Uberlândia, MG, Brazil. E-mail: evandrof@umuarama.ufu.br, baueralvarenga@pifpaf.com.br (4)USP, Instituto de Biociências, Dep. de Biologia, Rua do Matão, Travessa 14, № 321, Cidade Universitária, Caixa Postal 11461, CEP 05508-900 São Paulo, SP, Brazil. E-mail: srmatiol@ib.usp.br
\end{abstract}

\begin{abstract}
The objective of this work was to identify alterations in the histomorphology of the cortical bone tissue of broilers submitted to growing and finisher rations formulated with five different sources of phosphorus: dicalcium phosphate, simple superphosphate, triple superphosphate, monoammonium phosphate and Araxá rock phosphate. Histological images had their components segmented, and were called regions of interest (ROI). Images were analyzed through developed algorithms, using the SCILAB mathematical environment. Eleven features were considered in order to obtain a complete description of the bone images: percentage of bone by area, ROI area, ROI perimeters, ROI elongation, ROI angle and their respective standard deviations, besides entropy of ROI angles and a texture-oriented measure (lacunarity). The substitution of dicalcium phosphate in growing and finisher rations for any other tested source of phosphorus caused significant changes on the hystomorphology of the cortical broilers bones, for example: diminution of bone percentage by area, increase of lacuna area and worse matrix homogeneity. Changes were more pronounced in the Araxá rock phosphate treatments, with the highest fluorine content, than in simple superphosphate, triple superphosphate and monoammonium phosphate treatments, which were similar.
\end{abstract}

Index terms: histomorphology, macromineral sources, poultry nutrition.

\section{Histomorfometria óssea de frangos de corte submetidos a diferentes fontes de fósforo nas rações de crescimento e terminação}

\begin{abstract}
Resumo - O objetivo deste trabalho foi avaliar alterações histomorfológicas na região do osso cortical de frangos de corte alimentados, nas fases de crescimento e engorda, com rações contendo cinco diferentes fontes de fósforo - fosfato dicálcico, superfosfato simples, superfosfato triplo, fosfato monoamônio e fosfato de rocha de Araxá. Imagens histológicas foram digitalizadas, segmentadas em regiões de interesse (ROI) e analisadas por meio de algoritmos desenvolvidos no ambiente de programação SCILAB. Consideraram-se onze características para descrição das imagens: porcentagem de osso por área, área da ROI, perímetro da ROI, alongamento da ROI, ângulo da ROI, os respectivos desvios-padrão dessas medidas, a entropia dos ângulos das ROI e uma medida orientada de textura (lacunaridade). A substituição do fosfato dicálcico, nas rações de crescimento e engorda, por qualquer uma das outras fontes de fósforo testadas, causou mudanças significativas na histomorfologia do córtex ósseo dos frangos de corte, tais como: menor porcentagem de osso por área, aumento da área das lacunas e menor homogeneidade da matriz. As alterações foram mais pronunciadas nos tratamentos que receberam fosfato de rocha de Araxá, fonte de maior nível de flúor, do que nos tratamentos com superfosfato simples, superfosfato triplo e fosfato monoamônio, os quais foram semelhantes entre si.
\end{abstract}

Termos para indexação: histomorfologia, fontes de macrominerais, nutrição de frangos de corte.

\section{Introduction}

Bones represent the greatest mineral reserve of the body, containing about $99 \%$ of calcium, $88 \%$ of phosphorus, $80 \%$ of bicarbonate and $50 \%$ of magnesium. Calcium and phosphorus are the main minerals involved. Deficiencies in the equilibrium of calcium, phosphorus and $\mathrm{D}_{3}$ vitamin can cause serious damages to bone tissue 
formation, resulting in a deficient structure that can lead to problems of skeleton formation and sustentation, with the tibial dyschondroplasia (DT), valvus and varus deformation and the rickets being the most common problem in broilers (Leeson et al., 1995).

Most phosphorus content in plants is in phytic acid form. As monogastric animals do not synthesize the phytase enzyme, necessary for phytic acid liberation, phosphorus in vegetables has low bioavailability to those animals, which absorb just about one third of the cereals phosphorus. Hence, it is essential to complement phosphorus in the ration served to such animals (Denbow et al., 1995).

In Brazil, inorganic phosphorus supplementation is generally performed with dicalcium phosphate and bone flours. Normally, rock phosphate is not used, despite the great deposits of such materials found in this country. There are restrictions to the use of these rocks, once they possess high fluorine content, as demonstraded for Araxá rock phosphate (Rezende et al., 1999), and also because of scant information about its phosphorus absorption. However, there has been growing interest in evaluating the natural rock phosphate as an alternative low-cost phosphorus supply (Rezende et al., 1998; Veloso et al., 1998a, 1998b; Fernandes et al., 1999; Godoy \& Chicco, 2000; Rao \& Reddy, 2001a, 2001b, 2003).

The objective of this work was to identify possible alterations in the morphology of the cortical bone tissue of broilers submitted to growing and finisher rations formulated with different sources of phosphorus.

\section{Material and Methods}

The experiment was performed in a completely randomized design with five treatments and five replicates. Each treatment was composed of five experimental units for 30 fast growing broilers strain, totalizing 150 broilers for each treatment. Only the dicalcium phosphate was used as source of phosphorus supplementation in the starter ration (Table 1).

Broilers were fed on corn-soybean meal diets and the growing and finisher rations were supplemented with the following phosphorus sources: dicalcium phosphate (control treatment), simple superphosphate, triple superphosphate, monoammonium phosphate and Araxá rock phosphate (Tables 2 and 3 ).

Broilers were sacrificed with 49 days, when one bone piece of the medial third of the tibia diaphysis of the right thigh was collected from three broilers for treatment, totalizing three bones for each treatment. These bone tissue samples were fixed in $10 \%$ formaldehyde, decalcified in EDTA solution and embedded in paraffin. Five not serial thin sections with $7 \mu \mathrm{m}$ of thickness and $42 \mu \mathrm{m}$ of interval far from each other bone piece were obtained by microtome and stained with hematoxilin and eosin (HE), totalizing 15 replicates for each treatment. All the histological sections were transversal to the major bone axis in the Mid-cortex region and were analyzed through digitized images obtained in BX 40 Olympus microscope with objective of 10X, coupled to an Oly 200 Olympus camera connected to a PC microcomputer through a 3153 data Translation card.

Bone matrix regions were segmented through color threshold-based methodology (Costa \& Cesar Junior, 2001), producing a binary image in which the pixels corresponding to the lacunas and canals are identified by value of one and the bone matrix by value of zero.

The morphometric analyses were performed by algorithms developed in the SCILAB mathematical environment (Beletti \& Costa, 2003), considering several morphological features of the canals and image texture characterization. Each image was processed separately and had the bone canals segmented, yielding the regions of interest (ROI).

Table 1. Diet nutrient levels in pre-starter and starter rations.

\begin{tabular}{|c|c|c|}
\hline Nutrient & Pre-starter & Starter \\
\hline Dry matter (\%) & 88.81 & 88.96 \\
\hline Crude protein (\%) & 22.50 & 21.00 \\
\hline Crude fat $(\%)$ & 5.15 & 6.67 \\
\hline Crude fiber $(\%)$ & 4.20 & 4.00 \\
\hline Mineral matter $(\%)$ & 6.01 & 5.82 \\
\hline Calcium (\%) & 1.00 & 1.00 \\
\hline Phosphorus (\%) & 0.77 & 0.73 \\
\hline Available phosphorus (\%) & 0.50 & 0.47 \\
\hline Metabolizable energy $\left(\mathrm{kcal} \mathrm{kg}^{-1}\right)$ & $2,980.00$ & $3,100.00$ \\
\hline Arginine $(\%)$ & 1.56 & 1.45 \\
\hline Methionine (\%) & 0.58 & 0.55 \\
\hline Available methionine (\%) & 0.55 & 0.52 \\
\hline Cystine (\%) & 0.38 & 0.36 \\
\hline Available cystine (\%) & 0.32 & 0.30 \\
\hline Methionine + cystine $(\%)$ & 0.95 & 0.90 \\
\hline Available methionine + cystine $(\%)$ & 0.87 & 0.82 \\
\hline Lysine $(\%)$ & 1.26 & 1.16 \\
\hline Available lysine (\%) & 1.11 & 1.02 \\
\hline Treonine $(\%)$ & 0.88 & 0.82 \\
\hline Available treonine $(\%)$ & 0.75 & 0.70 \\
\hline Tryptophan (\%) & 0.26 & 0.24 \\
\hline Available tryptophan $(\%)$ & 0.22 & 0.20 \\
\hline Sodium $(\%)$ & 0.17 & 0.16 \\
\hline Chloride (\%) & 0.30 & 0.28 \\
\hline Potassium (\%) & 0.94 & 0.88 \\
\hline Magnesium (\%) & 0.20 & 0.19 \\
\hline Choline (mg) & 280.76 & 291.54 \\
\hline Linoleic acid (\%) & 2.68 & 3.43 \\
\hline
\end{tabular}


The bone matrix and ROI features were analyzed according to the following variables: percentage of bone by area (PBA): it is the black pixels percentage in the image that is possible to estimate the density of bone matrix in the material; ROI area (RA): is the average of the pixels number inside the ROI; standard deviation of the ROI area (SRA); ROI perimeter (RP): is the average of the sum of the distance between pixels along each ROI border considering two types of adjacencies: linear (1) and diagonal $\left(2^{0,5}\right)$; standard deviation of the ROI perimeter (SRP); ROI elongation (RE): is the average elongation of the ROI, in which the elongation was determined by the larger/smaller dispersion ration, obtained from principal component analysis (PCA); standard deviation of the ROI elongation (SRE); ROI angle (RAG): is the average angle of the ROI, in which angle is obtained from arc tangent of the relation between the eigenvectors obtained from the PCA and transformed in radians units, which varies from -90 to 90 radians; standard deviation of ROI angle (SRAG); entropy of RAG (E): is defined by the formula
$\mathrm{E}=-\sum$ pi. $\log (\mathrm{pi})$ where pi represents the relative frequency of the normalized angles values; lacunarity: is calculated by the gliding box method, which uses an $\mathrm{S}$ window with radius $r$ initially placed at the upper left corner of the binary image containing the ROI. The sum of the pixel values contained inside the box (S) is calculated as the gliding box is moved, pixel by pixel, to the right. $r$ values varying from one by one pixels, with minimum value 2 and maximum value 10, were used. For each $r$ value, the lacunarity at the window position was calculated as: $L_{r}=\log \left(\sigma / \mathrm{m}^{2}\right)$, in which $\sigma$ and $m$ are the standard deviation and the mean of the $\mathrm{S}$, respectively. The lacunarity $(\mathrm{L})$ value of each image is defined as:

$\mathrm{L}=\int_{2}^{10} \mathrm{~L}_{\mathrm{r}} \mathrm{ds}$.

According to these methods, 221 images were processed, corresponding to the following cases:

Table 2. Diet nutrient levels in growing ration.

\begin{tabular}{|c|c|c|c|c|c|}
\hline \multirow[t]{2}{*}{ Nutrient } & \multicolumn{5}{|c|}{ Treatments } \\
\hline & $\begin{array}{l}\text { Dicalcium } \\
\text { phosphate }\end{array}$ & $\begin{array}{c}\text { Simple } \\
\text { superphosphate }\end{array}$ & $\begin{array}{c}\text { Triple } \\
\text { superphosphate }\end{array}$ & $\begin{array}{c}\text { Monoammonium } \\
\text { phosphate }\end{array}$ & $\begin{array}{l}\text { Araxá rock } \\
\text { phosphate }\end{array}$ \\
\hline Dry matter $(\%)$ & 89.03 & 89.21 & 89.10 & 89.17 & 89.01 \\
\hline Crude protein $(\%)$ & 19.50 & 19.00 & 19.00 & 19.00 & 19.45 \\
\hline Crude fat $(\%)$ & 7.70 & 8.50 & 7.80 & 8.04 & 8.03 \\
\hline Crude fiber $(\%)$ & 3.80 & 3.68 & 3.71 & 3.70 & 3.71 \\
\hline Mineral matter (\%) & 5.40 & 6.43 & 5.61 & 6.00 & 5.65 \\
\hline Calcium $(\%)$ & 0.90 & 0.96 & 0.90 & 0.90 & 0.95 \\
\hline Phosphorus (\%) & 0.69 & 0.76 & 0.64 & 0.64 & 0.74 \\
\hline Available phosphorus (\%) & 0.45 & 0.42 & 0.42 & 0.42 & 0.42 \\
\hline Metabolizable energy $\left(\mathrm{kcal} \mathrm{kg}^{-1}\right)$ & $3,200.00$ & $3,200.00$ & $3,200.00$ & $3,200.00$ & $3,200.00$ \\
\hline Arginine $(\%)$ & 1.33 & 1.28 & 1.28 & 1.28 & 1.28 \\
\hline Methionine (\%) & 0.49 & 0.54 & 0.54 & 0.54 & 0.54 \\
\hline Available methionine (\%) & 0.46 & 0.51 & 0.51 & 0.51 & 0.51 \\
\hline Cystine $(\%)$ & 0.34 & 0.33 & 0.33 & 0.33 & 0.33 \\
\hline Available cystine (\%) & 0.28 & 0.27 & 0.27 & 0.27 & 0.27 \\
\hline Methionine + cystine $(\%)$ & 0.82 & 0.86 & 0.86 & 0.86 & 0.86 \\
\hline Available methionine + cystine $(\%)$ & 0.75 & 0.78 & 0.78 & 0.78 & 0.78 \\
\hline Lysine $(\%)$ & 1.05 & 1.09 & 1.09 & 1.09 & 1.09 \\
\hline Available lysine (\%) & 0.94 & 0.98 & 0.98 & 0.98 & 0.98 \\
\hline Treonine $(\%)$ & 0.76 & 0.73 & 0.73 & 0.73 & 0.74 \\
\hline Available treonine $(\%)$ & 0.65 & 0.62 & 0.62 & 0.62 & 0.62 \\
\hline Tryptophan (\%) & 0.22 & 0.21 & 0.21 & 0.21 & 0.21 \\
\hline Available tryptophan $(\%)$ & 0.18 & 0.18 & 0.18 & 0.18 & 0.18 \\
\hline Sodium (\%) & 0.16 & 0.19 & 0.18 & 0.19 & 0.18 \\
\hline Chloride $(\%)$ & 0.28 & 0.35 & 0.35 & 0.35 & 0.35 \\
\hline Potassium $(\%)$ & 0.81 & 0.78 & 0.78 & 0.78 & 0.78 \\
\hline Magnesium (\%) & 0.19 & 0.17 & 0.18 & 0.18 & 0.18 \\
\hline Choline (mg) & 306.85 & 518.66 & 530.73 & 526.54 & 525.50 \\
\hline Linoleic acid (\%) & 3.95 & 4.35 & 4.00 & 4.12 & 4.15 \\
\hline
\end{tabular}


phosphate (control group, 32 images), simple superphosphate (52 images), triple superphosphate (38 images), monoammonium phosphate (48 images), and Araxá rock phosphate (treatment groups, 51 images).

Principal component method is suitable for removing redundancies between features by uncorrelating them (Costa \& Cesar Junior, 2001). This method (Joliffe, 1986; Ripley, 1996) was applied in order to statistically compare the five treatment groups, by using the new variables space obtained from a linear transformation, which defines ten principal components (PC). Only the inicial $\mathrm{PC}$ were considered in this work because they concentrate the majority of the variance among the features. The PCA was conducted by using JPM version 3.02 (SAS Institute, 1994).

The purposes of the PCA test is to promote a linear transformation of the $\mathrm{N}$-dimensional features space, using their eigenvectors and covariance matrix, to find the rotation that maximizes the dispersion along each of the new axes.

In addition, the five treatments were compared, using a single feature at a time, through the Sidak Method at
$5 \%$ of probability. Finally, the distances between the data obtained for different treatments were calculated by the Mahalanobis distance (Mahalanobis, 1936) in the eleventh dimensional space of features. These statistical tests were conducted using the SPLUS 2000 PROF software.

\section{Results and Discussion}

The first principal component (PC-1), which carried about $48 \%$ of the date dispersion, led to separation of the dicalcium phosphate treatment from the others, while the other treatments led to unclear distinctions (Figure 1).

The other three consecutive PC (PC-2, PC-3 and PC-4) were responsible for almost $39 \%$ of the date dispersion, respectively, 23, 9 and 7. Finally, PC-5 to PC-10 summarized the remaining $13 \%$ of the date dispersion. Features that greatly collaborated to the dispersion assumed by $\mathrm{PC}-1$ were percentage of bone area (PBA), ROI area, ROI perimeter and their standard deviation (SRA and SRP) besides lacunarity.

Table 3. Diet nutrient levels in finisher ration.

\begin{tabular}{|c|c|c|c|c|c|}
\hline \multirow[t]{2}{*}{ Nutrient } & \multicolumn{5}{|c|}{ Treatments } \\
\hline & $\begin{array}{l}\text { Dicalcium } \\
\text { phosphate }\end{array}$ & $\begin{array}{c}\text { Simple } \\
\text { superphosphate }\end{array}$ & $\begin{array}{c}\text { Triple } \\
\text { superphosphate }\end{array}$ & $\begin{array}{l}\text { Monoammonium } \\
\text { phosphate }\end{array}$ & $\begin{array}{c}\text { Araxá rock } \\
\text { phosphate }\end{array}$ \\
\hline Dry matter $(\%)$ & 89.07 & 89.27 & 89.13 & 89.18 & 89.03 \\
\hline Crude protein $(\%)$ & 18.50 & 18.00 & 18.00 & 18.00 & 18.00 \\
\hline Crude fat $(\%)$ & 8.55 & 9.05 & 8.57 & 8.76 & 8.65 \\
\hline Crude fiber $(\%)$ & 3.68 & 3.57 & 3.59 & 3.58 & 3.57 \\
\hline Mineral matter (\%) & 5.08 & 5.76 & 5.22 & 5.54 & 5.85 \\
\hline Calcium (\%) & 0.85 & 0.85 & 0.85 & 0.85 & 0.88 \\
\hline Phosphorus (\%) & 0.61 & 0.66 & 0.57 & 0.57 & 0.67 \\
\hline Available phosphorus (\%) & 0.37 & 0.35 & 0.35 & 0.35 & 0.35 \\
\hline Metabolizable energy ( $\left.\mathrm{kcal} \mathrm{kg} \mathrm{kg}^{-1}\right)$ & $3,280.00$ & $3,280.00$ & $3,280.00$ & $3,280.00$ & $3,280.00$ \\
\hline Arginine $(\%)$ & 1.25 & 1.20 & 1.20 & 1.20 & 1.20 \\
\hline Methionine (\%) & 0.44 & 0.47 & 0.47 & 0.47 & 0.47 \\
\hline Available methionine (\%) & 0.40 & 0.44 & 0.44 & 0.44 & 0.44 \\
\hline Cystine & 0.33 & 0.31 & 0.32 & 0.32 & 0.32 \\
\hline Available cystine (\%) & 0.27 & 0.26 & 0.26 & 0.26 & 0.26 \\
\hline Methionine + cystine $(\%)$ & 0.76 & 0.77 & 0.77 & 0.77 & 0.77 \\
\hline Available methionine + cystine $(\%)$ & 0.69 & 0.70 & 0.70 & 0.70 & 0.70 \\
\hline Lysine (\%) & 0.99 & 1.01 & 1.00 & 1.00 & 1.00 \\
\hline Available lysine (\%) & 0.87 & 0.90 & 0.90 & 0.90 & 0.90 \\
\hline Treonine $(\%)$ & 0.71 & 0.69 & 0.69 & 0.69 & 0.69 \\
\hline Available treonine $(\%)$ & 0.62 & 0.59 & 0.59 & 0.59 & 0.59 \\
\hline Tryptophan (\%) & 0.21 & 0.20 & 0.19 & 0.20 & 0.19 \\
\hline Available tryptophan $(\%)$ & 0.17 & 0.17 & 0.17 & 0.17 & 0.17 \\
\hline Sodium (\%) & 0.16 & 0.18 & 0.18 & 0.18 & 0.18 \\
\hline Chloride $(\%)$ & 0.28 & 0.33 & 0.33 & 0.33 & 0.33 \\
\hline Potassium (\%) & 0.77 & 0.74 & 0.74 & 0.74 & 0.74 \\
\hline Magnesium (\%) & 0.18 & 0.17 & 0.18 & 0.18 & 0.18 \\
\hline Choline (mg) & 316.83 & 444.90 & 453.14 & 449.85 & 445.13 \\
\hline Linoleic acid $(\%)$ & 4.38 & 4.62 & 4.38 & 4.48 & 4.42 \\
\hline
\end{tabular}


It was observed that the features percentage of bone area, lacunarity, ROI area and ROI perimeter presented significant differences regarding the treatment containing dicalcium phosphate when compared to the other treatments (Table 4).

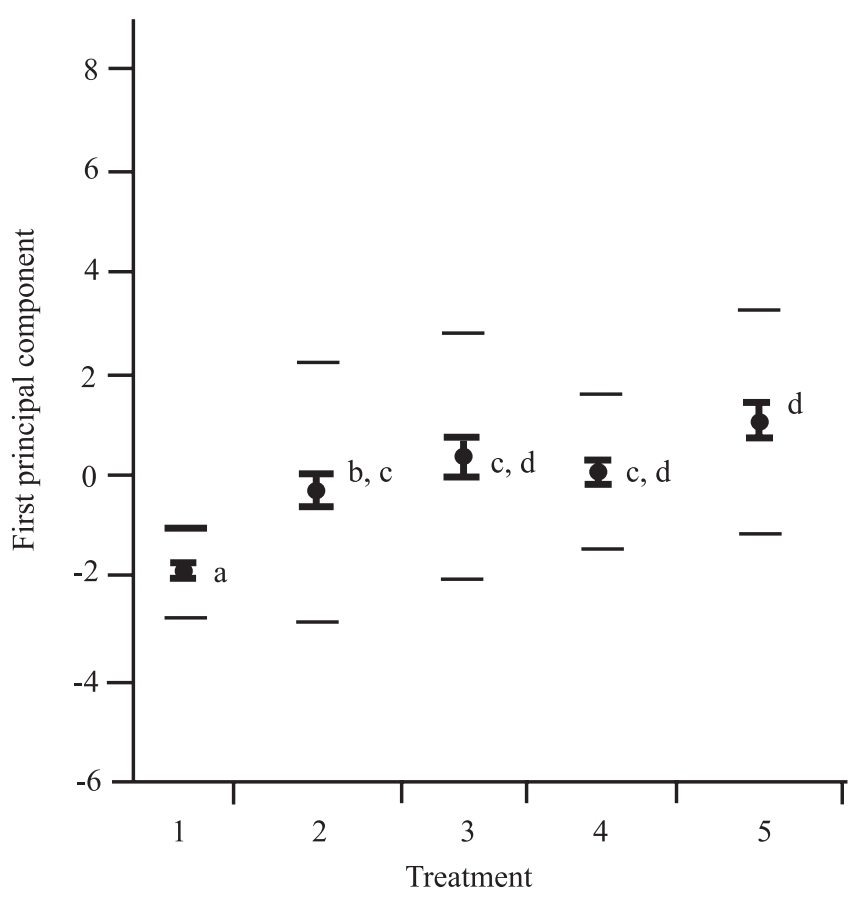

Figure 1. Different responses of the first principal component among the five treatment groups. Thick lines are the standard errors of the mean and the thin lines represent the standard deviations. Groups that do not share the same letter are significantly different between them, according the Tukey-Kramer HSD test (1, dicalcium phosphate; 2, simple superphosphate; 3, triple superphosphate; 4, monoammonium phosphate; 5, Araxá rock phosphate).
Differences between the treatment groups are also demonstrated by considering the Mahalanobis distance, with dicalcium phosphate treatment showing the largest distances from the other treatment groups, agreeing with the principal component analysis results, while simple superphosphate, triple superphosphate and monoammonium phosphate treatments exhibited shorter distance among them. Finally, the Araxá rock phosphate group presented an intermediate distance from the previous three treatments and the highest Mahalanobis distance was observed between the clusters obtained for Araxá rock phosphate and dicalcium phosphate treatments (Table 5).

Many works identified strong influence of different sources of phosphorus for broilers nutrition in terms of incidence of bone pathologies, content of bone ash and productive performance (Godoy \& Chicco, 2000; Rath et al., 2000; Willians et al., 2000; Rao \& Reddy, 2001a, $2001 \mathrm{~b}, 2003)$. There is little information about systematic use of quantitative image analysis methodologies in those recent works. The study of cortical bone in undermineralized histological slides can contribute to address, in a systematic and objective way, the importance of organic matrix geometry to the bone strength and biomechanical properties (Parfitt, 1984; Rath et al., 1999).

The results obtained by principal component analysis are in accordance with the distinct quality of nutrients present in each source of phosphorus. In this sense, dicalcium phosphate is known as the best source in terms of phosphorus bioavailability and lesser fluorine concentrations, which is expected to determinate a better bone histological architecture (Fernandes et al., 1999; Rezende et al., 1999; Godoy \& Chicco, 2000).

Table 4. Comparison of each feature analyzed among the treatments using Sidak Method(1).

\begin{tabular}{|c|c|c|c|c|c|c|c|c|c|c|c|}
\hline Treatment & PBA & RA & SRA & RP & SRP & $\mathrm{RE}$ & SRE & RAG & SRAG & $\mathrm{E}$ & $\mathrm{L}$ \\
\hline $\begin{array}{l}\text { Dicalcium } \\
\text { phosphate }\end{array}$ & $89.37 \mathrm{a}$ & $522.62 a$ & $632,50 \mathrm{a}$ & $117.87 \mathrm{a}$ & $77.87 \mathrm{a}$ & $0.37 \mathrm{ab}$ & $0.22 \mathrm{ab}$ & $12.17 \mathrm{a}$ & $59.02 \mathrm{ab}$ & $.64 \mathrm{a}$ & $13.85 \mathrm{a}$ \\
\hline $\begin{array}{l}\text { Simple } \\
\text { superphosphate }\end{array}$ & $83.52 b$ & $1,336.15 b$ & $1,657.02 \mathrm{ab}$ & $169.90 \mathrm{~b}$ & $117.53 \mathrm{ab}$ & $0.40 \mathrm{a}$ & $0.22 \mathrm{ab}$ & $-4.97 b$ & $58.91 \mathrm{ab}$ & $1.60 \mathrm{a}$ & $12.55 \mathrm{ab}$ \\
\hline $\begin{array}{l}\text { Triple } \\
\text { superphosphate }\end{array}$ & $82.43 b c$ & $1,403.74 b c$ & $2,197.31 b c$ & $179.08 \mathrm{~b}$ & $138.37 \mathrm{bcd}$ & $0.39 \mathrm{ab}$ & $0.23 \mathrm{a}$ & $-0.26 a b$ & $60.54 \mathrm{a}$ & $1.69 \mathrm{a}$ & $11.01 \mathrm{bc}$ \\
\hline $\begin{array}{l}\text { Monoammonium } \\
\text { phosphate }\end{array}$ & $81.65 b c$ & $1,318.78 b$ & $1,776.31 \mathrm{ac}$ & $177.45 b$ & $121.23 \mathrm{ac}$ & $0.40 \mathrm{a}$ & $0.22 \mathrm{ab}$ & $-4.20 b$ & $61.60 \mathrm{a}$ & $1.57 \mathrm{a}$ & $10.36 \mathrm{bc}$ \\
\hline $\begin{array}{l}\text { Araxá rock } \\
\text { phosphate }\end{array}$ & $79.55 \mathrm{c}$ & $1,845.76 \mathrm{c}$ & $2,287.94 b c$ & $220.73 c$ & $164.77 d$ & $0.35 b$ & $0.21 b$ & $1.54 \mathrm{ab}$ & $53.95 \mathrm{~b}$ & $1.63 \mathrm{a}$ & $9.54 \mathrm{c}$ \\
\hline
\end{tabular}

${ }^{(1)}$ Means in the same column, followed by the same letter are not different at $5 \%$ of probability; PBA: percentage of bone by area; RA: ROI area; SRA: standard deviation of the ROI area; RP: ROI perimeter; SRP: standard deviation of the ROI perimeter; RE: ROI elongation; SRE: standard deviation of the ROI elongation; RAG: ROI angle; SRAG: standard deviation of ROI angle; E: entropy of RAG; L: lacunarity. 
Percentage of Bone Area (PBA), ROI area (RA) and ROI perimeter (RP) were the most important variables considered in the PC-1 and, according to its values (Table 4), it is possible to conclude that the dicalcium phosphate treatment group had the best matrix formation, due to higher values observed in percentage of bone area and lower values for RA, RP. Therefore, animals from dicalcium phosphate treatment had the best bone strength comparing to other groups because of their compactness bone matrix.

These results are in agreement with the hypothesis that high fluorine content has an antagonic influence on the bone matrix formation (Bayley et al., 1990). The observation that Araxá rock phosphate and triple superphosphate diminished the matrix formation and produced higher ROI areas is also as expected.

In particular, the respective larger ROI areas and perimeters induced by the Araxá rock phosphate treatment, whose source has the highest fluorine concentration, could interfere with the bone mechanical properties (Rao \& Reddy, 2003). Also, Bayley et al. (1990), in studies with the fluor effects in mammalians, demonstrated that fluorine excess was affecting bone strength and increasing bone weakness, deformities and breakage incidence.

Another informative measurement applied is the lacunarity, which is a texture measurement capable of monitoring the homogeneity of digitized images that have important participation in the PC-1 composition, with larger lacunarity values being obtained for more homogenous textures (Mandelbrot, 1983; Plotnick et al., 1996). The lacunarity analysis of the treatments indicated that broilers fed on dicalcium phosphate or simple superphosphate presented more homogenous texture in their bone images comparing to the other sources utilized (Figure 2). These observations suggest that the apposition rate and bone turnover occurred in better controlled and homogenous fashion for these two mentioned treatments and that the bone geometry were characterized by less translational invariance along the image (Dougherty, 2001).

Substitution of dicalcium phosphate as unique source of phosphorus in growing and finisher rations for the other four sources proposed in these study causes significant modifications on the cortical bone

Table 5. Mahalanobis distance between the treatments ${ }^{(1)}$.

\begin{tabular}{|c|c|c|c|c|c|}
\hline Treatments & $\begin{array}{l}\text { Dicalcium } \\
\text { phosphate }\end{array}$ & $\begin{array}{c}\text { Simple } \\
\text { superphosphate }\end{array}$ & $\begin{array}{c}\text { Triple } \\
\text { superphosphate }\end{array}$ & $\begin{array}{c}\text { Monoammonium } \\
\text { phosphate }\end{array}$ & $\begin{array}{c}\text { Araxá rock } \\
\text { phosphate }\end{array}$ \\
\hline Dicalcium phosphate & 0 & 10.06 & 6.24 & 8.23 & 11.69 \\
\hline Simple superphosphate & & 0 & 2.13 & 1.92 & 4.70 \\
\hline Triple superphosphate & & & 0 & 1.36 & 3.92 \\
\hline Monoammonium phosphate & & & & 0 & 3.75 \\
\hline Araxá rock phosphate & & & & & 0 \\
\hline
\end{tabular}

(1)Mahalanobis distance between the column header treatment group and the row header treatment group.

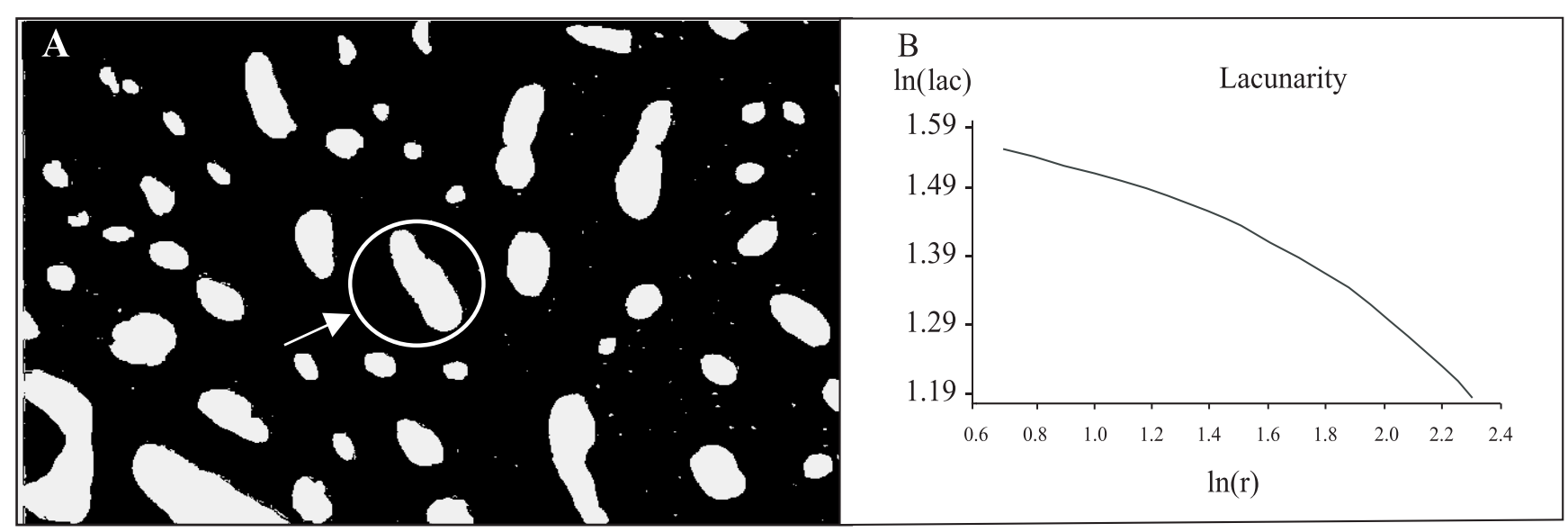

Figure 2. A: Binary image of cortical bone slide with an appointed circle around a ROI (region of interest). B: The respective lacunarity graphic of the image. 
histomorphology at different degrees, depending on the fluorine content (Rezende et al., 1999) of the substitutive phosphorus source. Measurements applied to characterize bone images on this study can be used in other approaches of bones histologycal evaluation.

\section{Conclusion}

Alternatives phosphorus sources in broilers growing and finisher rations promote different histomorphometric standards of the cortical bone when compared with dicalcium phosphate source.

\section{Acknowledgements}

To CNPq, Capes and Fapesp, for financial support.

\section{References}

BAYLEY, T.A.; HARRISON, J.E.; MURRAY, T.M.; JOSSE, R.G.; STURTRIDGE, W.; PRITZKER, K.P.; STRAUSS, A.; VIETH, R.; GOODWIN, S. Fluoride induced fractures: relation to osteogenic effect. Journal of Bone Mineral Research, v.1, p.217-222, 1990.

BELETTI, M.E.; COSTA, L.D. A systematic approach to multispecies sperm morphometric characterization. Analytical Quantitative Cytology and Histology, v.25, p.97-107, 2003.

COSTA, L. da F.; CESAR JUNIOR, R.M. Shape analysis and classification: theory and practice. $1^{\text {st }}$ ed. Boca Raton: CRC Press, 2001. 659p.

DENBOW, D.M.; RAVINDRAN, V.; KORNEGAY, E.T.; YI, Z.; HULET, R.M. Improving phosphorus availability in soybean meal for broilers by supplemental phytase. Poultry Science, v.74, p.1831-1842, 1995.

DOUGHERTY, G. A comparison of texture of the computed tomography and projection radiography images of vertebral trabecular bone using fractal signature and lacunarity. Medical Engineering and Physics, v.23, p.313-321, 2001.

FERNANDES, J.I.M.; LIMA, F.R.; MENDONÇA, C.K.; MABE, I.; ALBUQUERQUE, R.; LEAL, P.M. Relative bioavailability of phosphorus in feed and agricultural phosphates for poultry. Poultry Science, v.78, p.1729-1736, 1999.

GODOY, S.; CHICCO, C.F. Rawrock phosphates in laying hens' feeding. 1. Growing and prelaying period. Revista CientificaFacultad de Ciencias Veterinarias, v.10, p.486-493, 2000.

JOLIFFE, I.T. Principal component analysis. New York: SpringerVerlag, 1986. 271p.

LEESON, S.; DIAZ, G.J.; SUMMERS, J.D. Skeletal disorders. In: LEESON, S.; DIAZ, G.J.; SUMMERS, J.D. Poultry metabolic disorders and mycotoxins. $1^{\text {st }}$ ed. Guelph: University Books, 1995. $352 \mathrm{p}$.
MAHALANOBIS, P.C. On the generalized distance in statistic. Proceedings of the National Institute of Science of India, v.2, p.49-55, 1936.

MANDELBROT, B.B. The fractal geometry of nature. New York: Freeman, 1983. 480p.

PARFITT, A.M. Age related structural-changes in trabecular and cortical bone - celular mechanism and biomechanical consequences. Calcified Tissue International, v.36, p.123-128, 1984.

PLOTNICK, R.E.; GARDNER, R.H.; HARGROVE, W.W.; PRESTEGAARD, K.; PERLMUTTER, M. Lacunarity analysis: a general technique for analysis of spatial patterns. Physical Review, v.53, p.5461-5468, 1996.

RAO, S.V.R.; REDDY, V.R. Relative bio-availability and utilisation of phosphatic fertilisers as sources of phosphorus in broilers and layers. British Poultry Science, v.44, p.96-103, 2003.

RAO, S.V.R.; REDDY, V.R. Relative bio-availability of different phosphorus supplements in broiler and layer chicken diets. Asian Australasian Journal of Animal Sciences, v.14, p.979-985, 2001a.

RAO, S.V.R.; REDDY, V.R. Utilisation of different phosphorus sources in relation to their fluorine content for broilers and layers. British Poultry Science, v.42, p.376-383, $2001 \mathrm{~b}$.

RATH, N.C.; BALOG, J.M.; HUFF, W.E.; HUFF，G.R.; KULKARNI, G.B.; TIERCE, J.F. Comparative differences in the composition and biomechanical properties of tibia of seven- and seventy-two-week-old male and female broiler breeder chickens. Poultry Science, v.78, p.1232-1239, 1999.

RATH, N.C.; HUFF, G.R.; HUFF, W.E.; BALOG, J.M. Factors regulating bone maturity and strength in poultry. Poultry Science, v.79, p.1024-1032, 2000.

REZENDE, M.J.M.; VELOSO, J.A.F.; HOSSAIN, S.M. Desempenho de frangos de corte recebendo duas fontes de fósforo de acordo com a biodisponibilidade de fósforo e de cálcio. Arquivo Brasileiro de Medicina Veterinária e Zootecnia, v.50, p.705710, 1998.

REZENDE, M.J.M.; VELOSO, J.A.F.; TURCHETTI-MAIA, R.M.M. Effect of dietary flourine from Araxá rock phosphate on the hepatic production of cyclic-adenosine monophosphate in broilers. Arquivo Brasileiro de Medicina Veterinária e Zootecnia, v.51, p.477-484, 1999.

RIPLEY, B.D. Pattern recognition and neural networks. Cambridge: Cambridge University Press, 1996. 415p.

SAS INSTITUTE (Cary, Estados Unidos). Statistical software for the Macintosh. Cary, 1994.

VELOSO, J.A.F.; REZENDE, M.J.M.; HOSSAIN, S.M. Biodisponibilidade de cálcio de quatro suplementos de fósforo para frangos de corte. Arquivo Brasileiro de Medicina Veterinária e Zootecnia, v.50, p.73-79, 1998a.

VELOSO, J.A.F.; REZENDE, M.J.M.; HOSSAIN, S.M. Biodisponibilidade de flúor de quatro suplementos de fósforo para frangos de corte. Arquivo Brasileiro de Medicina Veterinária e Zootecnia, v.50, p.63-67, 1998 b.

WILLIAMS, B.; SOLOMON, S.; WADDINGTON, D.; THORP, B.; FARQUHARSON, C. Skeletal development in the meat-type chicken. Brithish Poultry Science, v.41, p.141-149, 2000.

Received on July 25, 2005 and accepted on July 6, 2006 